\title{
Combined Effect of Organic Manure and Leaching on Soil Salinity, Nitrate Availability and Ground Water Quality
}

\author{
P. Premanandarajah \\ Department of Agric-chemistry, Faculty of Agriculture, Eastern University Sri Lanka
}

*Corresponding Author: P. Premanandarajah, Department of Agric-chemistry, Faculty of Agriculture, Eastern University Sri Lanka

\begin{abstract}
A leaching column study was conducted by using amendments Farmyard manure (FYM), Gliricidia $(G)$, partially burnt paddy husk (PBPH) and tank silt (TS) alone and in combination of FYM and other three at recommendation. These eight including control (without amendments) replicated three times in a complete randomized design. Soil used was sandy loam saline with electrical conductivity as $13.1 \mathrm{dSm}^{-1}$ and $\mathrm{pH}$ as 7 . Amendments mixed soil was filled in leaching column and incubated for three weeks then was saturated. Once in two weeks $150 \mathrm{ml}$ of distilled water was added and leachate was collected and nitrate content was recorded. At the end of four leaching cycles soil nitrate content was recorded. Leachate nitrate content reduced drastically from $1^{\text {st }}$ to $2^{\text {nd }}$ and slightly from $2^{\text {nd }}$ to $4^{\text {th }}$ leaching. At the first leaching, nitrate leaching was higher in FYM and lowest in TS and was on par with control. Cumulative nitrate was lowest in TS and highest in FYM amended soil as 1089 and $2165 \mathrm{mg} / \mathrm{kg}$ respectively while in control was $852 \mathrm{mg} / \mathrm{kg}$. Soil nitrate content was lowest in control and highest in FYM+TS combination. Combined application of FYM and tank silt increased soil nitrate and reduced $\mathrm{pH}$ of saline soil. In addition FYM and tank silt combination reduced the nitrate leaching thereby this can protect the ground water from nitrate contamination.
\end{abstract}

Keywords: Soil nitrate, Organic Amendments, Saline soil

\section{INTRODUCTION}

Soil salinity is one of the major constraints limiting the expansion of cultivated areas and diminishing the productivity of rice lands. Excessive amounts of salts have an adverse effect on soil physical and chemical properties, soil microbiological processes and plant growth. The negative effects of salinization are intensified by the low levels of soil organic matter (Muhammad et al., 2005). Several methods have been proposed to reclaim salt-affected soils. The physical, chemical and biological properties of soil in salt-affected areas are improved by the application of organic matter, leading to enhanced plant growth and development, therefore, the application of organic matter for soil remediation is important for sustainable land use and crop productivity (Choudhary et al., 2004). Keeping in view the importance of organic amendments on the reclamation of salt affected soils, a leaching study was carried out by using locally available organic amendments to study the impact of sole and combined use of organic amendments with leaching on soil salinity and soil nitrate content in saline soils.

\section{MATERIALS AND METHODS}

The bulk soil (0.1ppm nitrate) from saline paddy land was collected. The soil group used in this study was Non-Calcic Brown Earth. Bulk soil samples were air-dried, ground to pass through a $2 \mathrm{~mm}$ sieve and mixed thoroughly. Organic amendments were collected from various places and allowed to air dry. Then those were sieved through sieve. Organic amendments used as soil amendments are Farmyard manure (FYM), Gliricidia (G), partially burnt paddy husk (PBPH) and tank silt (TS). All amendments were applied alone (4 treatments) and a combination of farmyard manure with other amendments ( 3 treatments) at the rate of recommendation. These eight treatments including control (without amendments) were replicated three times in a complete randomized design, giving a total of 24 leaching columns. Leaching columns were prepared by using polyvinyl chloride (PVC) tubes (5.4 
$\mathrm{cm}$ internal diameter and $42 \mathrm{~cm}$ height) and wooden stands. Bottom of the tubes were tightly covered with muslin cloth to prevent the entry of soil particles with the leachate and draining to the collection bottle. A funnel was laid at the bottom of each leaching column to facilitate the percolating water to move towards the collecting bottle.

Treatments used were: Farm yard manure $\left(\mathrm{T}_{1}\right)$, partially burnt paddy husk $\left(\mathrm{T}_{2}\right)$, Gliricidia $\left(\mathrm{T}_{3}\right)$, Tank silt $\left(\mathrm{T}_{4}\right)$, without amendments (Control) $\left(\mathrm{T}_{5}\right), \mathrm{T}_{1}+1 / 2 \mathrm{~T}_{2}\left(\mathrm{~T}_{6}\right), \mathrm{T}_{1}+1 / 2 \mathrm{~T}_{3}\left(\mathrm{~T}_{7}\right), \mathrm{T}_{1}+1 / 2 \mathrm{~T}_{4}\left(\mathrm{~T}_{8}\right)$.

According to the treatment, organic amendments were mixed with $950 \mathrm{~g}$ of soil and filled in each column to a height of $30 \mathrm{~cm}$ to maintain an equal bulk density of soil. Soil columns were placed vertically on wooden stands and allowed for incubation in moist condition for three weeks. After incubation, columns were filled with distilled water up to their saturation point. Once in two weeks $150 \mathrm{ml}$ distilled water was added to each leaching column and the leachate was collected. Altogether four leaching cycles were completed during the study period. Leachate collected at each leaching cycle was analyzed for its EC and nitrate content and after whole leaching cycle soil was analyzed for its nitrate content, EC and $\mathrm{pH}$. The data were analyzed statistically by using SAS application and comparisons among treatments were tested with Duncan Multiple Range Test (DMRT) at 5\% significant level.

\section{RESULTS AND DiSCUSSION}

Soil leachate Nitrate content $\left(\mathrm{NO}_{3}{ }^{-}\right)$.

Table 1. Effect of organic amendment on periodical changes on nitrate content in soil leachate

\begin{tabular}{|l|c|c|c|c|}
\hline \multirow{2}{*}{ Treatments } & \multicolumn{4}{c|}{ In soil leachate $\mathbf{N O}_{3}{ }^{-}(\mathbf{m g} / \mathbf{L})$} \\
\cline { 2 - 5 } & $1^{\text {st }}$ & $2^{\text {nd }}$ & $3^{\text {rd }}$ & $4^{\text {th }}$ \\
\hline Farmyard manure $\left(\mathrm{T}_{1}\right)$ & $16.05^{\mathrm{a}}$ & $5.18^{\mathrm{a}}$ & $0.40^{\mathrm{b}}$ & $0.15^{\mathrm{b}}$ \\
\hline partially burnt paddy husk $\left(\mathrm{T}_{2}\right)$ & $10.75^{\mathrm{d}}$ & $1.63^{\mathrm{c}}$ & $0.33^{\mathrm{bc}}$ & $0.19^{\mathrm{b}}$ \\
\hline Gliricidia $\left(\mathrm{T}_{3}\right)$ & $13.09^{\mathrm{bc}}$ & $5.06^{\mathrm{a}}$ & $0.61^{\mathrm{a}}$ & $0.33^{\mathrm{a}}$ \\
\hline Tank silt $\left(\mathrm{T}_{4}\right)$ & $6.15^{\mathrm{e}}$ & $5.10^{\mathrm{a}}$ & $0.38^{\mathrm{b}}$ & $0.19^{\mathrm{b}}$ \\
\hline Control $\left(\mathrm{T}_{5}\right)$ & $6.71^{\mathrm{e}}$ & $3.62^{\mathrm{b}}$ & $0.25^{\mathrm{cd}}$ & $0.14^{\mathrm{b}}$ \\
\hline Farmyard manure + partially burnt paddy husk $\left(\mathrm{T}_{6}\right)$ & $14.79^{\mathrm{ab}}$ & $4.90^{\mathrm{a}}$ & $0.24^{\mathrm{d}}$ & $0.16^{\mathrm{b}}$ \\
\hline Farmyard manure + Gliricidia $\left(\mathrm{T}_{7}\right)$ & $14.67^{\mathrm{ab}}$ & $2.43^{\mathrm{b}}$ & $0.03^{\mathrm{f}}$ & $0.23^{\mathrm{c}}$ \\
\hline Farmyard manure + Tank silt $\left(\mathrm{T}_{8}\right)$ & $12.34^{\mathrm{cd}}$ & $3.01^{\mathrm{c}}$ & $0.12^{\mathrm{e}}$ & $0.04^{\mathrm{c}}$ \\
\hline
\end{tabular}

Means followed by the same letter are not significantly different according to the DMRT at 5\% level.

The results revealed that there was a significant influence of organic amendments on nitrate $\left(\mathrm{NO}_{3}{ }^{-}\right)$ content in leachates as $\mathrm{P}$ value is less than 0.05 . The nitrate content in leachate was reduced with leaching. The change was drastic from 1 st to $2^{\text {nd }}$ leaching and then was slide from $2^{\text {nd }}$ to $3^{\text {rd }}$ leaching. In $1^{\text {st }}, 2^{\text {nd }}$ and $3^{\text {rd }}$ leachate impact of organic manures on nitrate content was higher, and the impact was minute at final leaching. The highest nitrate content in $1^{\text {st }}$ leachate was due to the influence of organic amendments on nitrate release and retention capacity in soil. It was supported by Rajendra Prasad \& Misra (2001). At the first leaching (after 3 weeks), significantly least nitrate value was observed in tank silt and was on par with control. Significantly highest value was observed in FYM and was followed by FYM with $G$ and FYM with PBPH combinations. This may be due to higher nitrate nitrogen addition and leaching efficiency by FYM. This was supported that combined application of organic amendments like farm yard manure increased the availability of $\mathrm{N}, \mathrm{P}, \mathrm{K}$ and the organic carbon content (Subburaj and Ramaswami, 1994) and infiltration rate (IR) improved up to $88.9 \%$ with FYM application (Kahlown and Azam, 2003).

In $2^{\text {nd }}$ leachate, among all treatments, significantly least nitrate content was observed in PBPH. Significantly highest value was observed in FYM and was on par with TS, Gliricidia and FYM with PBPH. In third leachate, among all treatments, the significantly least nitrate was observed in FYM with Gliricidia combination and significantly highest amount was observed in Gliricidia. Removal of salts in the first and second leachates was high, probably because most of the soluble salts were get dissolved and washed with the leachates. In third leachate the salt content was relatively low compared to first and second leachates. It seems that the salts available in soil solution may get washed with leaching. A similar result of high removal of salts in initial leachate has been reported by Ghafoor et al. (1988). 
Considering the cumulative amount of nitrate in all four leachates, the lowest was in the soil amended with TS and highest was in FYM amended soil that of 1089 and $2165 \mathrm{mg} / \mathrm{kg}$ respectively while control nitrate content was $852 \mathrm{mg} / \mathrm{kg}$. This clearly confirms that the FYM supply nutrients to the salt affected soil (Sarwar et al., 2008).).

\section{Soil Nitrate Content $\left(\mathrm{NO}_{3}{ }^{-}\right)$}

Table 2. Effect of organic amendment and leaching on soil nitrate content

\begin{tabular}{|l|l|}
\hline \multicolumn{1}{|c|}{ Treatments } & \multicolumn{1}{c|}{$\mathbf{N O}_{3}{ }^{-1}(\mathbf{m g} / \mathbf{k g})$} \\
\hline Farmyard manure $\left(\mathrm{T}_{1}\right)$ & $55.3^{\mathrm{ab}}$ \\
\hline partially burnt paddy husk $\left(\mathrm{T}_{2}\right)$ & $22.6^{\mathrm{cd}}$ \\
\hline Gliricidia $\left(\mathrm{T}_{3}\right)$ & $33^{\text {bcd }}$ \\
\hline Tank silt $\left(\mathrm{T}_{4}\right)$ & $24^{\mathrm{cd}}$ \\
\hline Control $\left(\mathrm{T}_{5}\right)$ & $14^{\mathrm{d}}$ \\
\hline Farmyard manure + partially burnt paddy husk $\left(\mathrm{T}_{6}\right)$ & $48^{\mathrm{abc}}$ \\
\hline Farmyard manure + Gliricidia $\left(\mathrm{T}_{7}\right)$ & $58.6^{\mathrm{ab}}$ \\
\hline Farmyard manure + Tank silt $\left(\mathrm{T}_{8}\right)$ & $76^{\mathrm{a}}$ \\
\hline
\end{tabular}

Means followed by the same letter are not significantly different according to the DMRT at $5 \%$ level.

There was significant influence of organic amendments on nitrate content of soil during study period as $\mathrm{P}$ value is less than 0.05 . Among the treatments, significantly lowest soil nitrate content was recorded in control. Significantly highest value was observed in combination of FYM and tank silt and was followed by FYM + Gliricidia combination, FYM was followed by Gliricidia. This may be due to the nutrient content and retention capacity of and internal characteristics of amendments. The results clearly showed that FYM provides more nitrate to the soil than the other amendments. Even though, nitrate content of sole tank silt amended soil was lowest, the nitrate content of soil amended with FYM and tank silt was highest, this may be due to the impact of tank silt on soil nitrate retention or increase nitrate content of soil by converting the other forms of nitrogen into nitrate. Though FYM supply more nitrogen the soil nitrate content in sole FYM amendment was lower. This may be due to high leaching loss in sole FYM application (table 1). The beneficial effect of tank silt on improving the soil nutrient status was reported by Ramesh (2001) who confirmed that tank silt enhanced total and available nitrogen content of soil. At the end of experiment, the nitrate amount was increased in control without addition of any nitrogen sources. This explains the effect of leaching in terms of nitrate content in saline soils; leaching may increase the availability of nitrogen in saline soil by increasing the activity of micro organism through removal of soil toxicity (Tejada \&Gonzalez, 2005).

Table 3. Effect of organic amendment and leaching on soil pH

\begin{tabular}{|l|c|c|}
\hline \multicolumn{1}{|c|}{ Treatments } & \multicolumn{2}{c|}{ Soil pH } \\
\cline { 2 - 3 } & Initial soil & Amended soil \\
\hline Farmyard manure $\left(\mathrm{T}_{1}\right)$ & 7.8 & $7.44 \mathrm{a}$ \\
\hline partially burnt paddy husk $\left(\mathrm{T}_{2}\right)$ & 7.8 & $7.12 \mathrm{ab}$ \\
\hline Gliricidia $\left(\mathrm{T}_{3}\right)$ & 7.8 & $7.46 \mathrm{a}$ \\
\hline Tank silt $\left(\mathrm{T}_{4}\right)$ & 7.8 & $7.31 \mathrm{ab}$ \\
\hline Control $\left(\mathrm{T}_{5}\right)$ & 7.8 & $7.47 \mathrm{a}$ \\
\hline Farmyard manure + PBPH $\left(\mathrm{T}_{6}\right)$ & 7.8 & $7.40 \mathrm{a}$ \\
\hline Farmyard manure + Gliricidia $\left(\mathrm{T}_{7}\right)$ & 7.8 & $7.40 \mathrm{a}$ \\
\hline Farmyard manure + Tank silt $\left(\mathrm{T}_{8}\right)$ & 7.8 & $7.35 \mathrm{~b}$ \\
\hline
\end{tabular}

Means followed by the same letter are not significantly different according to the DMRT at 5\% level.

The table shows shows that the $\mathrm{pH}$ was ultimately decreased by amendments. Although, the initial $\mathrm{pH}$ same for all treatment, there was a slide variation in soil $\mathrm{pH}$ among treatment at the end of experiment. This may due to the behavior on the decomposition and carbon dioxide $(\mathrm{CO} 2)$ release to the soil. This $\mathrm{CO} 2$ dissolves in soil water and forms an acid and many other organic acids which are also produced during decomposition. These acid counter - act salinity and alkalinity of the soil and push the soil reaction towards 'neutrality'.

At final stage highest $\mathrm{pH}$ was recorded on control (7.47) this may be due to leaching effect. In soils amended with sole FYM and Gliricidia and FYM with PBPH and Gliricidia combinations the $\mathrm{pH}$ was slightly lower than control but there was no significant variation. Decrease in $\mathrm{pH}$ due to the 
application of organic manures could be due to the release of organic acids during decomposition of OM (Walker et al., 2003). Near neutral pH was recorded in sole PBPH and tank silt treatment (7.12 and 7.31 respectively). This may be due to the nature and amount of acids released during the decomposition of PBPH and tank silt than other manures.

Table 4. Effect of organic amendment and leaching on soil electrical conductivity

\begin{tabular}{|l|c|c|}
\hline \multirow{2}{*}{\multicolumn{1}{|c|}{ Organic amendments }} & \multicolumn{2}{c|}{ Electrical conductivity(EC) dSm } \\
\cline { 2 - 3 } & \multicolumn{1}{|c|}{ Initial soil } & Amended soil \\
\hline Farmyard manure $\left(\mathrm{T}_{1}\right)$ & 13.1 & $1.07^{\mathrm{bcd}}$ \\
\hline partially burnt paddy husk $\left(\mathrm{T}_{2}\right)$ & 13.1 & $0.97^{\mathrm{d}}$ \\
\hline Gliricidia $\left(\mathrm{T}_{3}\right)$ & 13.1 & $1.37^{\mathrm{abc}}$ \\
\hline Tank silt $\left(\mathrm{T}_{4}\right)$ & 13.1 & $1.5^{\mathrm{abc}}$ \\
\hline Control $\left(\mathrm{T}_{5}\right)$ & 13.1 & $1.0^{\mathrm{cd}}$ \\
\hline Farmyard manure + partially burnt paddy husk $\left(\mathrm{T}_{6}\right)$ & 13.1 & $1.4^{\text {abcd }}$ \\
\hline Farmyard manure + Gliricidia $\left(\mathrm{T}_{7}\right)$ & 13.1 & $1.53^{\mathrm{ab}}$ \\
\hline Farmyard manure + Tank silt $\left(\mathrm{T}_{8}\right)$ & 13.1 & $1.83^{\mathrm{a}}$ \\
\hline
\end{tabular}

Means followed by the same letter are not significantly different according to the DMRT at 5\% level.

\section{Soil electrical conductivity}

In soil analysis, results revealed that significant changes in EC of soil after final leaching. The initial EC of soil sample was $13.1 \mathrm{dSm}^{-1}$. Among the treatments, significantly highest EC of soil was recorded in the FYM + TS combination. Significantly least EC was recorded in the PBPH amended soil. The reason for the highest EC may due to the release of inorganic nutrients by decomposition of organic manure (Chhipa and Lal, 2003) and the internal characteristics of tank silt.

\section{CONCLuSion}

Leaching plays an important role in terms of reducing EC in saline soil. The organic amendments along with leaching improve the leaching efficiency of saline soils either it is applied sole or in combination. Leaching is good strategy for the reclamation of saline soil, even though; alone leaching is not enough to improve the entire physicochemical properties of soil. Leaching with organic amendments is the best way to reclamation of saline soil in all forms. Partially burnt paddy husk amended soil showed lower EC in soil than other organic amendments.

Nitrogen rich amendments supply ample amount of nitrate into saline soil, and due to their low retention capacity the excess will get lost through leaching. Although, tank silt is providing low amount of nitrate compared to Gliricidia and FYM, due to its high nitrogen (available) retention capacity, soil nitrogen availability is higher in saline soil leached with tank silt and FYM than other amendments. Therefore, combined application of organic amendments like FYM and tank silt increased the availability of nitrate in Saline soil and also reduced $\mathrm{pH}$ of saline soil to 7.4. In addition FYM and tank silt combination reduced the nitrate leaching thereby this can protect the ground water from nitrate contamination.

\section{REFERENCES}

Chhipa, B.R. and Lal, P. (2003). Reclamation of salt affected soils. In: Salt affected soils and crop production (Eds.). Agrobios (India), Jodhpur. Pp. 94-113.

Choudhary, O.P., Josan, A.S., Bajwa, M.S. and L. Kapur. (2004). Effect of sustained sodic and saline-sodic irrigation and application of gypsum and farmyard manure on yield and quality of sugarcane under semiarid conditions. Field Crops Research 87: 103-116.

Ghafoor,A., Muhammed, S,, Ahmed, N. and M. A. Main, (1988)."Indices for the estimation of ESP from SAR of soil solution",Pakistan Journal of Science,vol.39-40 : 89-98.

Iqbal, M ,Hassan, A. U.L. and Lal, R 2007 Nutrient content of maize and soil organic matter status under various tillage methods and farmyard manure levels. Soil \& Plant Science .57 (4)

Kahlown, M.A. and A. Muhammad, (2003). Effect of saline drainage effluent on soil health and crop yield, Agricultural-Water-Management. 62: 2, 127-138.

Muhammad, S., Müller, T. and R. G. Joergensen ,(2005). Relationships between soil biological and other soil properties in saline and alkaline arable soils from the Pakistani Punjab. 
Rajendra Prasad and B. N. Misra . 2001 Effect of addition of organic residues, farmyard manure and fertilizer nitrogen on soil fertility in rice-wheat cropping system. Journal Archieves of agronomy and soil science. 46(5-6) pp $455-463$.

Ramaswami, P.P., and G.V. Kothandaraman, (1985). In:Proceedings of the Workshop on Coir Research. Coir House Cochin, Kerala, India.

Sarwar, G., Hussain, N., Schmeisky, H., Suhammad, S., Ibrahim, M., Ahmad, S. 2008. Efficiency of various organic residues for enhancing rice-wheat production under normal soil conditions. Pak. J. Bot. 40, 2107 2113.

Subburaj, D. and P.P. Ramaswami, (1994). Influence of amendment on the nutrient availability in typic ustipsamments. Madras Agric. Journal. 72(11): 605-608.

Subramanian, P., Dhanapal, R., Sanil, P., Palaniswami, C., Sairam, C.V., and Maheswarappa. H.P.(2005). Glyricidia sepium as green manure in improving soil fertility and productivity of coconut under coastal littrol sandy soil. Journal of Plantation Crops, 33(3): 179-183.

Tejada, M. \& J.L. Gonzalez, (2005). Beet vinasse applied to wheat under dry land conditions affects soil properties and yield. European Journal of Agronomy, Vol. 23, No 4:336-347.

Citation: P. Premanandarajah, " Combined Effect of Organic Manure and Leaching on Soil Salinity, Nitrate Availability and Ground Water Quality ", International Journal of Research in Environmental Science, vol. 3, no. 4, p. 24-28, 2017. http://dx.doi.org/10.20431/2454-9444.0304004

Copyright: () 2017 Authors. This is an open-access article distributed under the terms of the Creative Commons Attribution License, which permits unrestricted use, distribution, and reproduction in any medium, provided the original author and source are credited. 